\title{
Axiální spondylartritida
}

\author{
Leona Procházková', Vladimír Červeňák², Miroslav Souček¹ \\ 'Revmatologická ambulance II. interní kliniky LFMU a FN u sv. Anny v Brně \\ ${ }^{2} K l i n i k a$ zobrazovacích metod LF MU a FN u sv. Anny v Brně
}

\section{Souhrn}

Axiální spondylartritida (axSpA) je společným názvem pro neradiografickou formu onemocnění i radiografickou axiální spondylartritidu, známou též pod označením ankylozující spondylitida. Onemocnění se typicky manifestuje v mladém věku, je charakterizováno postižením osového skeletu a v nejtěžší formě může vést až $k$ obrazu úplné ankylózy páteře. Etiologie axSpA není doposud rozluštěna, nicméně je zjevný genetický podklad, především vazba na HLA-B27 antigen. Mezi klinickými projevy dominuje chronická bolest zejména dolní části zad vzniklá před 45. rokem věku, u velké části pacientů splňuje charakteristiku tzv. zánětlivé bolesti. Kromě osového skeletu je u axiální spondylartritidy časté i postižení periferního skeletu v podobě entezitidy, artritidy a méně často i daktylitidy. Právě entezitida je v současnosti považována za charakteristický znak celé skupiny spondylartritid. Typická pro axSpA je častá prítomnost mimoskeletálních projevů v podobě uveitid, idiopatických střevních zánětů a psoriázy. V diagnostice axSpA došlo v posledních letech $\mathrm{k}$ významnému pokroku zejména v oboru zobrazovacích technik. Pomocí magnetické rezonance Ize identifikovat i časné fáze onemocnění ještě před rozvojem strukturálních lézí. Také novější koncept celé skupiny spondylartritid, odvíjející se od klasifikačních kritérií ASAS (Assessment of SpondyloArthritis international Society) z roku 2009, prispěl k časnější diagnostice onemocnění, a to zejména podtržením významu asociace $s$ HLA-B27 antigenem a prítomnosti periferních a mimokloubních projevů. Nesteroidní antirevmatika a blokátory TNFa (tumor necrosis factor a) jsou účinnou terapií axSpA, která byla nedávno rozšírena o blokádu interleukinu 17.

Klíčová slova: axiální spondylartritida - biologická léčba - entezitida - magnetická rezonance - mimokloubní manifestace - neradiografická axiální spondylartritida - sakroiliitida

\section{Axial spondyloarthritis}

\section{Summary}

Axial spondyloarthritis (axSpA) is a common name for the non-radiographic form of the disease and radiographic axial spondyloarthritis, known as ankylosing spondylitis (AS). The disease is typically manifested at a young age, characterized by affection of axial skeleton, and in the most severe form can lead to complete ankylosis of the spine. Etiology of diseases have not yet been clarified, however, the genetic background, especially the binding to HLA-B27 antigen, is obvious. Clinical manifestations are dominated by chronic pain in the lower pain or buttocks that occurred in young age, in a large proportion of patients having the character of so-called inflammatory pain. In addition to the axial skeleton, axSpA there is also common affection of peripheral skeleton in the form of enthesitis, arthritis, and less often dactylitis. At present, enthesitis is considered as a hallmark of the entire spondyloarthritis group. Typical for axSpA is the frequent presence of extraskeletal manifestations in the form of uveitis, idiopathic intestinal inflammation and psoriasis. In the axSpA diagnosis, significant advances have been made in recent years in the field of imaging techniques. Magnetic resonance imaging can also identify the early stage of the disease before the development of structural lesions. Also, the newer concepts of the entire spondyloarthritis group, based on the 2009 ASAS (Assessment of SpondyloArthritis international Society) classification criteria, contributed to early diagnosis of the disease, and in particular to the underlying importance of association with HLA-B27 antigen and the presence of peripheral and non-articular manifestations. Non-steroidal anti-rheumatic drugs (NSAIDs) and TNFa blockers are effective axSpA therapy, which has been recently enhanced by interleukin 17 blockade (IL17).

Key words: axial spondyloarthritis - biological treatment - enthesitis - extraarticular manifestations - magnetic resonance imaging - non-radiographic axial spondyloarthritis - sacroiliitis 


\section{Úvod}

Axiální spondylartritida ( $\mathrm{xxSpA}$ ) je chronické, zánětlivé onemocnění postihující převážně axiální skelet. Označení axiální spondylartritida zahrnuje jak onemocnění s již prokazatelnými strukturálními změnami sakroiliakálního (SI) skloubení nebo páteře (radiografická axSpA, známá též pod označením ankylozující spondylitida - AS), tak i stavy bez tohoto strukturálního poškození, označované jako neradiografická axSpA (nr-axSpA). $U$ těchto nemocných může, ale nemusí v čase dojít k rozvoji strukturálních změn, část pacientů zůstává bez strukturálního poškození. Tato odlišnost vedla k úvahám, zdali se jedná o jednu nozologickou jednotku, nebo o dvě odlišná onemocnění. Pacienti s radiografickou i neradiografickou formou však mají stejnou tíži symptomů, u neradiografické formy je vyšší zastoupení žen a hodnoty zánětlivých markerů jsou nižší [1].

Onemocnění mưže postihnout všechny etáže páteře a v pokročilých stadiích může vést k významnému omezení hybnosti až úplné ankylóze. Charakteristickým znakem axSpA je sakroiliitida a entezitida, typickým klinickým projevem je bolest zad, často zánětlivého charakteru. Onemocnění se rozvíjí v mladším věku, nejčastěji do 40 let. Významná je vazba na HLA-B27 antigen (HLA-B27ag), jehož pozitivita zvyšuje riziko vzniku pro AS nejméně 50krát. Prevalence axiální SpA je udávána mezi $0,5-1,4 \%$ obyvatel, u AS je poměr postižení muži : ženy $2-3: 1$, u neradiografické axSpA je postižení obou pohlaví rovnoměrné [2].

\section{Etiologie a patogeneze \\ Genetické faktory}

Př́čina onemocnění není doposud známá, předpokládá se spolupodíl faktorů genetických a zevního prostředí, zvažován je i podíl infekčních agens. Z genetických asociací je nejvýznamnější a nejdéle známá asociace s HLA-B27 antigenem, u AS je jeho př́tomnost popisována v 74-89\%, nicméně ankylozující spondylitidou onemocní pouze malá část nosičů HLA-B27ag, jeho podíl na dědičnosti AS je tedy odhadován na asi 23 \%. Vlastní patofyziologická role HLA-B27ag není objasněna, existuje několik hypotéz. Kromě HLA-B27 je známa asociace minimálně 2 dalších genetických lokusů s AS: gen pro ERAP 1 (endoplasmic reticulum aminopetidase) kódující aminopeptidázu endoplazmatického retikula, jež se účastní na př́pravě peptidů pro prezentaci imunitním efektorovým buňkám prostřednictvím molekul MHC (major histocompatibility complex) I třídy a gen pro IL-23R (receptor pro interleukin 23), který aktivuje pomocné T-lymfocyty produkující IL17 a další prozánětlivé buňky [3].

\section{Střevní mikrobiom}

AxSpA je klinicky asociována s idiopatickými střevními záněty (idiopathic inflammatory bowel disease - IBD), psoriázou a reaktivními artritidami. Porucha bariérové funkce střeva nebo kůže a následná expozice imunitního systému mikroorganizmům má pravděpodobně význam v patogenezi axSpA. O tom, že střevní mikro- biom může hrát významnou roli v patogenezi axSpA, svědčí mimo jiné práce prokazující jeho alteraci u axSpA. U více než 50 \% pacientů s axSpA byl prokazován subklinický střevní zánět, včetně jeho vazby na vyšší aktivitu axSpA nebo významnější rozsah zánětlivého postižení SI skloubení. Tuto teorii podporují i některé společné genetické asociace mezi AS a IBD (IL12B, IL23R) [4,5].

\section{Entezitidy}

Zvýšená exprese IL23 vede u zvířecích modelů k rozvoji entezitid, což podporuje teorii o významu IL23 v patogenezi entezitid. Rezidenční $C D 4^{+}$a CD8 ${ }^{+} \mathrm{T}$-buňky v entezích reagují na IL23 nadprodukcí IL17 a jiných prozánětlivých cytokinů. Osa IL17/IL23 je považována za možný patogenetický mechanizmus podílející se na rozvoji axSpA, blokáda IL17 je v současnosti jednou z terapeutických možností u axSpA [6].

\section{Rozvoj strukturálních změn}

$K$ rozvoji zánětlivého postižení $u$ axSpA dochází mezi chrupavkou a kostí zejména v oblasti SI skloubení, páteře a v oblasti entezí. Mechanický stres může hrát roli v iniciaci a pravděpodobně i v udržení zánětlivého stavu. To může, svým způsobem, vysvětlovat predilekční postižení zejména zatěžovaných oblastí skeletu [7]. Kromě zánětu je axSpA charakterizována také kostní novotvorbou $v$ těchto lokalitách. Novotvorba kostní tkáně se zdá být důsledkem předchozího zánětlivého poškození a může být součástí reparačního procesu s cílem stabilizace. Právě ovlivnění kostní novotvorby je významným terapeutickým problémem.

\section{Faktory zevního prostředí}

Mezi rizikové faktory zevního prostředí patří jednoznačně kouření, Je asociováno s vyšší aktivitou axSpA, významnějším funkčním postižením i horší kvalitou života. U pacientů kuřáků s časnou axSpA dochází ke vzplanutí onemocnění v mladším věku, mají vyšší klinickou aktivitou onemocnění i větší rozsah zánětlivého postižení SI skloubení dle zobrazení magnetickou rezonancí (MRI) [8].

\section{Klinické projevy}

Bolest zad

Typickým klinickým projevem axSpA je chronická bolest zad trvající déle než 3 měsíce. Bolest má většinou plíživý charakter, nejčastěji postihuje dolní část páteře. Typická je ranní ztuhlost nad půl hodiny, odeznívající s pohybovou aktivitou a znovu se objevující v klidu. Časté je zvýraznění bolesti zad $v$ noci, zejména nad ránem. $U$ většiny pacientů splňuje bolest zad charakteristiku zánětlivé bolesti (tab. 1). Alternující bolest hýždí jako možný klinický projev sakroiliitidy je také jedním z typických projevů axSpA (tzv. buttock pain). Postižení hrudní páteře je vcelku časté, bolest entezí v oblasti hrudní stěny je popisována u více než 1 třetiny pacientů $s$ axSpA a může být zdrojem diferenciálně diagnostických obtíží. K postižení krční páteře dochází většinou v pozdějších stadiích onemocnění. 


\section{Periferní projevy onemocnění}

Přibližně u 1 třetiny pacientů je prítomno postižení kyčlí, které významně přispívá $\mathrm{k}$ funkčnímu omezení a až u $8 \%$ pacientů je nutno provést v průběhu onemocnění náhradu kyčelního kloubu. Postižení ramenního kloubu je přinejmenším stejně obvyklé [9].

Artritida a entezitida jsou nejčastější periferní manifestací axSpA, vyskytují se u asi 30-50 \% pacientů. Periferní entezitida je typickým znakem pro celou skupinu spondylartritid. Jedná se o zánět $v$ místě úponu ligament a vazů na kost, nejčastěji v oblasti patní kosti (entezitida distálního úponu Achillovy šlachy, úponu plantární fascie), postižena však může být kterákoliv enteze. $V$ rámci axSpA se může vyskytnout artritida periferních kloubů, nejčastěji v podobě oligoartritidy, predilekčně na dolních končetinách. $V$ prípadě postižení více kloubů jednoho prstu se současnou tendovaginitidou flexorů vzniká daktylitida (párkovitý prst).

\section{Mimokloubní manifestace}

Pro celou skupinu spondylartritid je typický častý výskyt extraskeletálních manifestací (extra-articular manifestations - EAM), které mohou být i první známkou onemocnění, a mají tedy význam i v rámci diagnostiky. Mezi 3 nejvýznamnějši mimokloubní projevy patří uveitida, idiopatické střevní záněty (IBD) a lupénka.

Pacienti s axSpA a doprovodnou AAU jsou častěji HLA-B27 pozitivní a muži, zatímco u pacientů s psoriázou a IBD je incidence HLA-B27 pozitivity i mužské pohlaví méně časté $[10,11]$.

\section{Uveitida}

Uveitida je nejčastější EAM, vyskytuje se typicky ve formě akutní přední uveitidy (acute anterior uveitis - AAU). Postihuje asi 30-40 \% pacientů s AS. Charakteristickými klinickými projevy jsou epizody zarudnutí, bolesti postiženého oka, fotofobie, zvýšená slzivost provázená poruchou vizu, vyskytující se většinou unilaterálně, zř́́dka synchronizovaná s aktivitou SpA. Častá je rekurence na protilehlém oku, HLA-B27 pozitivní pacienti mají signifikantně horší průběh atak. Pro stanovení diagnózy je nutné oftalmologické vyšetření (vyšetření štěrbinovou lampou) [10].

\section{Idiopatické střevní záněty}

IBD (Crohnova nemoc či ulcerózní kolitida) provázejí axSPA približně u 5-10 \% pacientů, přičemž Crohnova nemoc je častější. U více než poloviny pacientů $s$ axSpA jsou však dle histologického vyšetření detekovatelné mikroskopické známky střevního zánětu kolon a distálního ilea bez klinických projevů IBD [11].

\section{Psoriáza}

Lupénka se vyskytuje u více než $10 \%$ pacientů s axSpA.

\section{Další manifestace}

Ostatní manifestace axSpA se vyskytují vzácněji - např. plicní postižení v podobě plicní fibrózy je prokazatelné $\mathrm{u}<1 \%$ pacientů, v důsledku omezené hybnosti hrudní páteře a ankylózy kostovertebrálních skloubení může dojít k rozvoji restriktivní ventilační poruchy. Nejčastějším typem kardiálního postižení je aortitida, postihující zejména kořen aorty a ascendentní aortu a vedoucí k aortální insuficienci. Vyskytují se také převodní poruchy různé tíže a závažnosti.

\section{Komorbidity}

Komorbidity nejsou prímým projevem vlastní axSpA, jsou však důsledkem zánětlivého onemocnění a mohou být velmi významným faktorem ovlivňujicím kvalitu života, $\checkmark$ některých prípadech i faktorem ovlivňujícím mortalitu pacientů s axSpA. Jsou tedy nedílnou součástí diagnostiky i managementu terapie axSpA.

\section{Osteoporóza}

Osteoporóza (OP) a osteopenie se vyskytuje približně u čtvrtiny pacientů s axSpA, včetně časných fází spondylartritidy. Kombinace spinální rigidity dané tvorbou syndesmofytů a ankylózou intervertebrálních kloubů s porózou trabekulární kosti je rizikovým faktorem pro vznik vertebrálních fraktur, které jsou u AS časté, někteří autoři udávají výskyt až u $10 \%$ pacientů s AS. Náhle vzniklá bolest $v$ oblasti krku a zad u pacienta $s$ axSpA by měla vést $\mathrm{k}$ vyloučení vertebrální fraktury pomocí $C T$ vyšetření. Osteoporóza u pacientů s axSpA souvisí s aktivitou onemocnění, čehož důkazem je i fakt, že u pacientů léčených anti-TNF preparáty většinou dochází k zástavě poklesu BMD. Vyšetření kostní denzity by tedy mělo být součástí komplexní péče o pacienty s axSpA [12,13].

\section{Kardiovaskulární onemocnění}

Zvýšené riziko kardiovaskulárních (KV) onemocnění u pacientů se SpA je důsledkem kombinace chronického zánětlivého procesu a ostatních rizikových faktorů, jako jsou obezita, nízká fyzická aktivita, hypertenze, kouření, porucha lipidového spektra. Riziko může být dále násobeno léky užívanými v terapii axSpA. Běžnou součástí managementu axSpA je tedy i monitoring a terapie KV komplikací [14].

\section{Klasifikace axSpA}

Axiální spondylartritida je obvykle diagnostikována revmatologem. Časté je však opožděné stanovení diagnózy,

\section{Tab. 1. Charakteristika zánětlivé bolesti zad} (kritéria dle ASAS)

zánětlivá bolest zad př́tomna při $\geq 4$ kritériích (senzitivita 79,6 \%, specificita $72,4 \%$ )
1 věk při prvních projevech onemocnění $<40$ let
2 plíživý začátek obtíží
3 zlepšení obtiží s rozcvičením
4 žádné zlepšení v klidu
5 bolesti $v$ druhé polovině noci 
zpoždění činí až 9 let a je z velké části důsledkem opožděného odeslání pacienta ke specializovanému vyšetření. Také v minulosti užívaná tzv. modifikovaná Newyorská klasifikační kritéria byla jedním z důvodů opožděné diagnózy, protože jejich součástí byl průkaz již pokročilých strukturálních změn (sakroiliitida II. stupně oboustranně nebo III. a vyššího stupně jednostranně dle RTG vyšetření) [15]. Požadavek průkazu strukturálních změn, které jsou i vzhledem k relativně pomalé progresi radiografického poškození přítomny se zpožděním, neumožňoval diagnostiku časnějších fází onemocnění. Navíc je hodnocení nižších stupňů sakroiliitidy v RTG obraze obtižné. Dalším a neméně důležitým důvodem opožděného stanovení diagnózy je rozmanitost př́znaků axSpA.

\section{Klasifikační kritéria ASAS}

$\checkmark$ roce 2009 byla publikována klasifikačních kritéria ASAS (Assessments in Ankylosing Spondylitis International Society) pro axSpA a v roce 2011 kritéria pro periferní spondylartritidu [16]. Rozlišují fenotyp onemocnění s predominantně axiální manifestací a predominantně periferním postižením. Tato kritéria klasifikují axSpA prítomností chronické bolesti zad trvající déle než 3 měsíce se vznikem před 45. rokem věku. Obsahují jednak větev s průkazem sakroiliitidy (pomocí RTG nebo MRI) a jednak tzv. klinickou větev, v níž je základním požadavkem průkaz HLA-B27 antigenu, obě doplněny o př́tomnost dalších klinických projevů jako je zánětlivý charakter bolesti zad, periferní a exatraartikulární projevy, terapeutická odpověd' na podávání NSA nebo rodinná anamnéza spondylartritidy. Součástí jsou také laboratorní nálezy v podobě
HLA-B27 pozitivity (pro zobrazovací větev) a elevace CRP (schéma 1).

Klasifikační kritéria jsou vzhledem k absenci diagnostických kritérií často používána za účelem stanovení diagnózy, což může být $v$ př́padě nezkušeného hodnotitele problematické. Je vždy třeba přihlížet i k hodnotě negativních nálezů a na druhé straně respektovat možnost jiné etiologie přiznaků, které se zdají být pro axSpA specifické. Taktéž váha jednotlivých klinických projevů v rámci klasifikačních kritérií není identická.

\section{Diagnostika \\ Anamnéza a klinické vyšetření}

Klinické vyšetření a důkladná anamnéza (zejména dotazy na délku a charakter bolesti zad, pozvolný vznik obtízí, cílený dotaz na extraskeletální manifestace, rodinná anamnéza SpA) jsou nezbytným základem diagnostiky axSpA. Při klinickém vyšetření páteře může být přitomna palpační bolest SI skloubení, v pokročilejších stadiích onemocnění jsou zjevné deformity páteře, zejména hyperkyfóza torakálního segmentu páteře, vyrovnaná bederní lordóza (sulcus dorsalis persistens) a zkrácení distancí v jednotlivých etážích postižené páteře [17].

\section{Laboratorní diagnostika}

Pro diagnostiku AxSpA nejsou k dispozici konkrétní specifické laboratorní testy. Hodnoty zánětlivých markerů (CRP a FW) jsou zvýšeny jen u asi 35-50 \% pacientů, zvýšení CRP je prediktorem radiografické progrese a taktéž lepší terapeutické odpovědi na biologickou terapii. Důležitým je stanovení HLA-B27 antigenu, jehož pozitivita sama

\section{Schéma 1. Axiálni a periferni SpA dle klasifikačnich kritérii ASAS. Upraveno podle [29]}

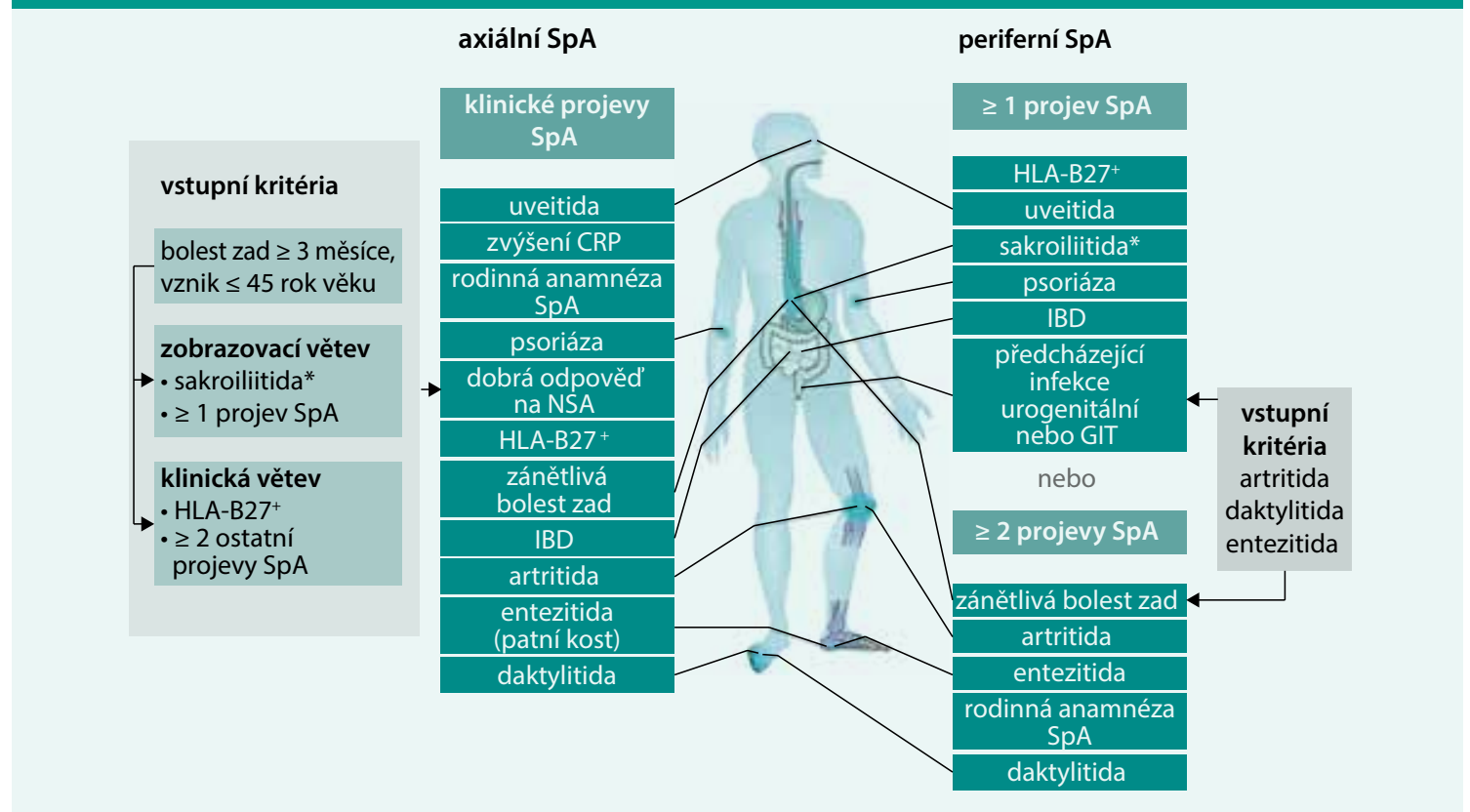

*sakroiliitida dle zobrazovacích metod: aktivní (akutní) zánět dle MRI SI skloubení nebo definitivní sakroiliitida dle modifikovaných Newyorských kritérií 
o sobě však není diagnostická. Má význam při podezření na axSpA, založeném na klinických a ostatních nálezech. Byly identifikovány některé další potenciální biomarkery asociované s rozvojem strukturálních změn (matrix-metaloproteináza 3, vaskulární endoteliální růstový faktor, kalprotektin, visfatin), které by mohly do budoucna identifikovat pacienty s rizikem radiografické spinální progrese [18]. V klinické praxi se však používá pouze již zmiňované CRP.

\section{Zobrazovací metody}

Zobrazovací vyšetřovací metody jsou zásadní pro správnou a časnou diagnózu axSpA, stejně tak pro diferenciální diagnostiku onemocnění. Protože SI skloubení je postiženo $u$ většiny pacientů, je jeho vyšetření základem diagnostiky a součástí klasifikačních kritérií.

Pro průkaz sakroiliitidy je RTG sakroiliakálního skloubení doporučen jako první zobrazovací vyšetření. Postižení SI skloubení se vyskytuje i u pacientů v časné fázi onemocnění (do 3 let u asi 30-50 \%). Vzhledem k anatomickému charakteru SI skloubení je vhodná šikmá projekce nebo projekce dle Fergusona. Rozsah postižení může být různý - od počátečních minimálních změn v podobě neostrosti kontur subchondrální kosti, přes subchondrální sklerózu, erozivní změny, obraz pseudo-

\section{Obr. 1. MRI STIR sekvence - vlevo periartikulárně na sakrálni i ilické straně rozsáhlý edém kostni dřeně}

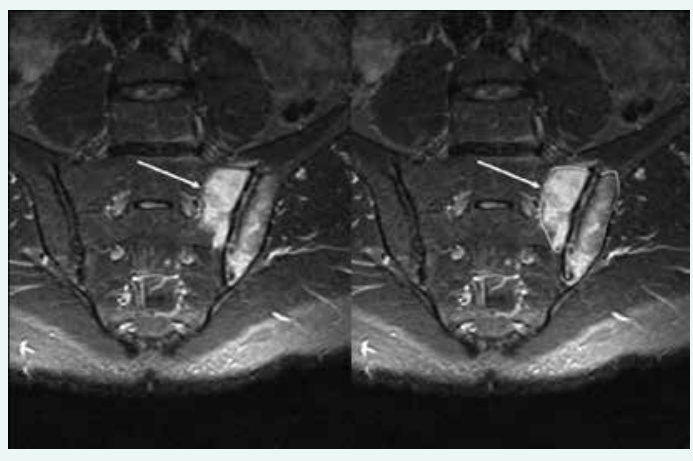

rozšiření kloubní štěrbiny až do obrazu parciální nebo kompletní ankylózy kloubu. Mezi typické RTG nálezy v oblasti páteře patří kvadratizace obratlových těl (vyrovnání kontur obratlů periostální reakcí), přemostující syndesmofyty (osifikace periferní části anulus fibrosus), fúze apofyzeálních skloubení, která v kombinaci s mnohočetnými syndesmofyty a kalcifikacemi spinálních ligament může vést až k obrazu „bambusové hole“. U pacientů s podezřením na axSpa založeným na klinických projevech a negativním RTG nálezem je vhodné vyšetření MRI. Známky sakroiliitidy dle MRI jsou obrazem aktivních zánětlivých změn, zatímco radiografické změny jsou již důsledkem proběhlého zánětu.

Pro diagnostiku a diferenciální diagnostiku axSpA jsou použitelné následující sekvence MRI: průkaz aktivní sakroiliitidy (edém kostní dřeně) v T2 vážené sekvenci s potlačením tukové tkáně (nejčastěji např. STIR sekvence short tau inversion recovery), pro zobrazení chronických změn (eroze, skleróza, tuková degenerace) je vhodná sekvence se senzitivitou pro tukovou tkáň (T1 vážená). Aplikace kontrastní látky není přínosnější než nativní zobrazení. Při indikaci MRI vyšetření je zcela zásadní volba správné vyšetřovací metodiky (výše uvedené zobrazení T2w s potlačením tukové tkáně) a dostatečná zkušenost při hodnocení nálezů. Průkaz edému kostní dřeně dle stanovených kritérií má stejnou hodnotu pro klasifikaci onemocnění jako sakroiliitida dle RTG (obr. 1). Normální nález na MRI sakroiliakálního skloubení však nevylučuje neradiografické stadium axSpA. V prípadě přetrvávajícího podezření na axSpA a negativním nálezu na MRI sakroiliakálního skloubení je vhodné vyšetření zobrazením magnetickou rezonancí s odstupem zopakovat. MRI změny jsou prokazatelné i v oblasti páteře, pro diagnostické účely však nejsou nutné, mohou být součástí diferenciální diagnostiky.

Mezi další zobrazovací metody používané v diagnostice periferních projevů onemocnění patří ultrasonografie (USG). Její využití se dostává do popředí zejména v diagnostice entezitid, protože klinické hodnocení entezitidy v oblasti patní kosti může být problematické. V USG obraze je evidentní nález pozitivního dopplerovského mapovaní průkazem aktivní entezitidy (obr. 2).

Obr. 2. Ultrasonografický obraz vřetenovitého rozšǐreni Achillovy šlachy s průkazem pozitivniho power-dopplerovského mapováni při obrazu entezitidy Achillovy šlachy

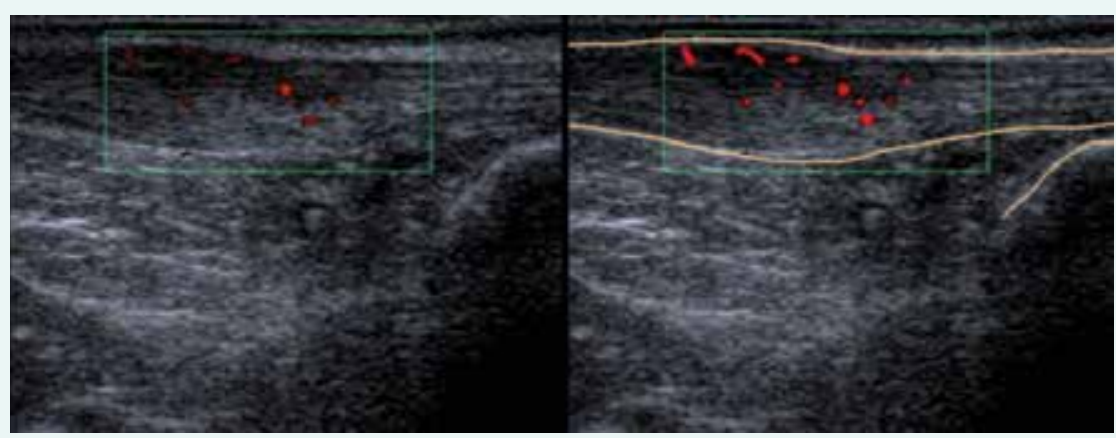


CT vyšetření SI skloubení je velmi exaktní v hodnocení strukturálních změn, nicméně kombinace RTG a MRI je většinou v tomto směru dostačující. Tzv. low-dose CT SI skloubení může být v opodstatněných prípadech nejasného nálezu jistou možností [19].

\section{Diferenciálni diagnostika}

Nejčastější diferenciální diagnózou pro axSpA jsou degenerativní onemocnění páteře, osteoartróza SI skloubení, diskopatie, v pokročilejších fázích onemocnění pak difuzní idiopatická skeletální hyperostóza (DISH).

\section{Screening u pacientů s chronickou bolestí zad}

Chronická bolest zad je široce rozšířeným symptomem, ale jen malá část pacientů, kteří si na ni stěžují, trpí axSpA. V diferenciální diagnostice bolesti zad se uplatňuje zejména odlišení mechanické bolesti zad, která má na rozdíl od zánětlivé bolesti zad většinou akutní začátek s kratším trváním symptomů, kratší ranní ztuhlostí a je provázena zhoršením při cvičení, eventuálně je přítomen neurologický deficit. Často zde také chybí noční maximum bolestí (tab. 2).

Vzhledem k výše popisovanému zpoždění v diagnóze u axSpA, byly vyvíjeny četné screeningové algoritmy s cílem časnějšího záchytu pacientů s axSpA (schéma 2.)

\begin{tabular}{|l|c|c|}
\hline $\begin{array}{l}\text { Tab. 2. Rozdílná charakteristika zánětlivé } \\
\text { a mechanické bolesti zad. Upraveno dle [30]. }\end{array}$ \\
\hline $\begin{array}{l}\text { zánětlivá bolest } \\
\text { zad }\end{array}$ & $\begin{array}{c}\text { mechanická bolest } \\
\text { zad }\end{array}$ \\
\hline věk při vzniku obtíží & $<45$ let věku & kdykoliv \\
\hline začátek obtíží & pozvolný & akutní \\
\hline trvání symptomů & $>$ než 3 měsíce & většinou < týdny \\
\hline ranní ztuhlost & $>30$ min & $<30$ min \\
\hline noční bolest & častá (zejména & většinou chybí \\
\hline efekt cvičení & v 2 polovině noci) & zhoršení \\
\hline bolest SI skloubení & clepšení & chybí \\
\hline neurologický deficit & neobvyklý & možný \\
\hline
\end{tabular}

\section{Terapie}

Cílem terapie axiální spondylartritidy je redukce symptomů, zachování hybnosti a flexibility páteře, minimalizace funkčního omezení a také rizika komplikací [20]. Součástí terapeutické rozvahy je také přihlédnutí k př́itomnosti mimokloubních projevů onemocnění.

Základem nefarmakologické terapie je pravidelné cvičení s cílem zachování hybnosti a rozsahu pohybů. Samostatné domácí cvičení je účinné, individuální nebo skupinové cvičení pod dohledem se zdá být efektivnější. Součástí nefarmakologické terapie je i edukace pacienta.

\section{Nesteroidní antirevmatika}

Nesteroidní antirevmatika (NSA), včetně selektivních inhibitorů cyklooxygenázy 2, jsou lékem první volby s cílem potlačit bolest a ztuhlost. Kontinuální užívání v plné terapeutické dávce je doporučováno v případě aktivního a symptomatického onemocnění, v prípadě minimálních projevů u stabilizovaného onemocnění je volbou podání on demand [21]. Nebyl prokázán význam trvalého podávání NSA v období remise. Dávkování se odehrává dle klinických projevů, je nutné zohlednit biologický poločas léku s cílem ovlivnit i noční bolesti a ranní ztuhlost. U pacientů, u kterých nelze dosáhnout kontroly onemocnění pomocí NSA nebo je u nich terapie NSA kontraindikována, je doporučena biologická terapie. Za neúčinnou se přitom považuje léčba plnou terapeutickou dávkou NSA po dobu alespoň 4 týdnů bez pozitivní odezvy, přičemž by měla být vyzkoušena alespoň 2 různá NSA [22].

\section{Biologická terapie}

Bezesporu nejúčinnější v terapii axSpA jsou biologické léky. Biologická terapie je indikována u pacientů s aktivní AS i neradiografickou axSpA po selhání standartní terapie (tab. 3). Biologická léčba je směřována do center biologické terapie.

Nejdéle jsou používány inhibitory TNFa (TNFi). V mnoha randomizovaných kontrolovaných studiích i následně open-label studiích byla ověřena účinnost všech $5 \mathrm{TNFi}-$ adalimumabu, certolizumabu, etanerceptu, golimumabu i infliximabu. Bez ohledu na odlišný způsob aplikace (subkutánní, intravenózní) a rozdílné dávkovací interva-

Schéma 2. Schéma diagnostického algoritmu pro časné odesláni pacienta k revmatologovi. Upraveno dle [28]

chronická bolest zad trvající $\geq 3$ měsíce

vznik prvních symptomů $<45$. rokem věku

nebo

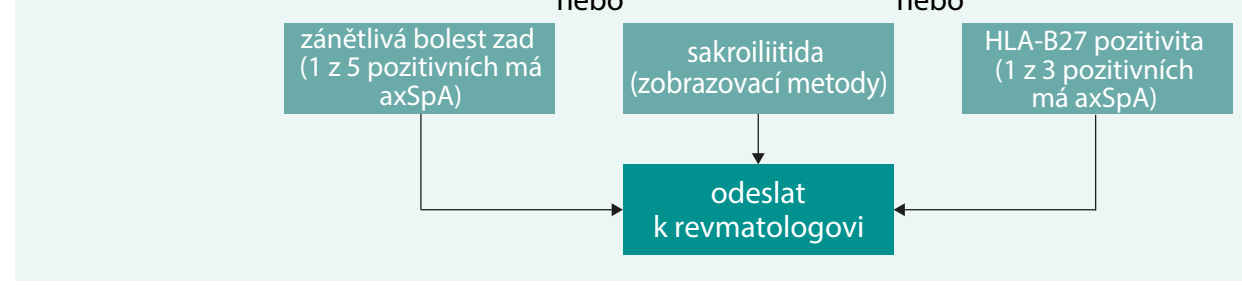

nebo 
ly byl opakovaně prokázán rychlý a setrvalý efekt v ovlivnění subjektivních i objektivních projevů onemocnění (tab. 5). TNFi jsou účinné u axiálních i periferních projevů onemocnění. Terapie TNFi je také účinná v ovlivnění mimoskeleletálních projevů (AAU, IBD i psoriázy), přičemž je znám rozdílný efekt monoklonálních protilátek a solubilního receptoru: etanercept není účinný v terapii IBD, má limitovaný efekt na uveitidy [20]. V současnosti se kromě TNF inhibitorů, které jsou v terapii axSpA používány již od roku 2003, dostávají na trh ještě další skupiny biologik $s$ jiným mechanizmem účinku. Jsou to zejména blokátory IL17, jejichž první zástupce sekukinumab je indikován k léčbě AS v 1 . linii terapie [23] (tab. 4).

V případě selhání efektu prvního TNFi Ize provést změnu (switch) biologika na další biologický lék. Nabízí se možnost switche na další TNFi, tato možnost je prokazatelně účinná, nicméně efekt klesá s každým dalším TNFi. Druhou možností je switch na lék s jiným mechanizmem účinku - v prípadě axSpA tedy na sekukinumab.

$\checkmark$ prípadě dosažení remise a ukončení terapie TNFi dochází bohužel u většiny pacientů k relapsu onemocnění (75-90 \%), bezpečnější se v tomto směru zdá stra- tegie snížení dávky biologika (snížení dávky nebo prodloužení dávkovacího intervalu).

\section{Ostatní terapie}

Analgetika slouží pouze jako přídatná terapie k ovlivnění bolesti, zejména při kontraindikaci NSA, samotná terapie analgetiky či opioidy není u axSpA účinná.

Účinná je lokální aplikace glukokortikoidů do postižených periferních kloubů nebo entezí, včetně aplikace do SI skloubení. Dlouhodobá systémová kortikoterapie nemá v terapii axSpA evidenci účinnosti.

V terapii periferních kloubních projevů jsou účinné konvenční syntetické chorobu modifikující léky (csDMARDs) - indikována je terapie sulfasalazinem (2-3 g/den, úvodní dávka $500 \mathrm{mg} /$ den s postupným navýšením). V prípadě sulfasalazinu je $v$ několika pracích popsán i určitý preventivní efekt proti rozvoji uveitid. Sulfasalazin ani jiná csDMARDs však nejsou účinná v terapii axiálních projevů nebo v ovlivnění entezitid [24].

\section{Možnosti inhibice radiografické progrese}

Zamezení radiografické progrese, zejména kostní novotvorby u axSpA, je jedním z nejvýznamnějších pro-

\section{Tab. 3. Indikace biologické terapie AS a neradiografické axSpA dle doporučeni České revmatologické} společnosti (ČRS). Upraveno podle [18]

\section{diagnóza}

ankylozující spondylitida dle NY/ASAS kritérií

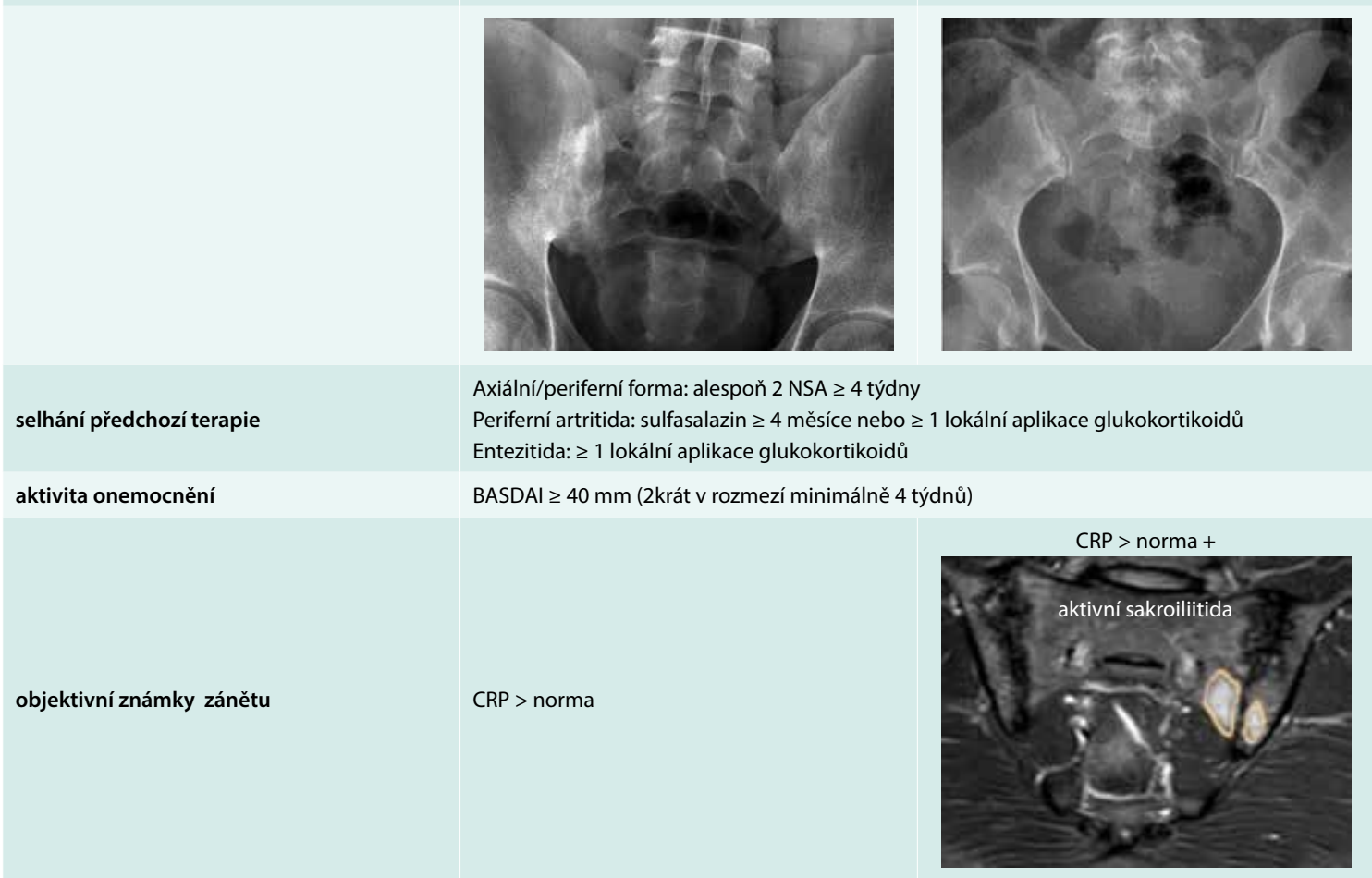

neradiografická axSpA dle ASAS kritérií

Hodnocení efektu biologické terapie - pokles BASDAI po 3 měsících léčby o $50 \%$ nebo absolutní pokles o 2 body (0-10 bodů). Index BASDAI (Bath Ankylosing Spondylitis Disease Activity Index) - subjektivní hodnocení aktivity pacientem, za aktivní je považován BASDAI $\geq 40 \mathrm{~mm}$ (škála 0-100 mm).

NY kritéria - Newyorská kritéria 
blémů v terapie tohoto onemocnění. Radiografická progrese onemocnění je sice celkově pomalá a také do této fáze onemocnění nedospějí všichni pacienti s nr-axSpA, nicméně $v$ případě progredujících strukturálních změn dochází k těžkému funkčnímu postižení. Určitými prediktory RTG progrese jsou vyšší vstupní hodnoty CRP, prítomnost syndesmofytů na počátku onemocnění, kouření a mužské pohlaví.

Úvodní data neprokazovala účinnost TNFi na strukturální progresi po 2-4 letech terapie [25]. Dle novějších evidence je zřejmé, že časná terapie a terapie delší než 4 roky může zpomalovat radiografickou progresi axSpA [26]. Několik prací prokázalo vliv kontinuálního podávání NSA na radiografickou progresi u pacientů s elevací CRP [27]. Další studie však tyto závěry nepotvrdily, vzhledem k užití odlišných NSA (COX-2 selektivní vs neselektivní NSA) je tak nutné další ověření těchto výsledků [28]. Nadějné jsou výsledky hodnocení rentgenové progrese z klinických studií se sekukinumabem, po 2 letech byla prokázána jen minimalní radiografická progrese u více než 80 \% pacientů a podle recentně prezentovaných výsledků je tento efekt setrvalý i po 4 letech terapie [23,31].

\section{Závěr}

Diagnostika axiální spondylartritidy není jednoduchým úkolem, žádný jednotlivý klinický projev, laboratorní test nebo zobrazovací nález není ani nezbytný ani dostačující pro stanovení diagnózy. Vyšetřeni revmatologem by měli být mladí pacienti s nevysvětlitelnou bolestí zad trvající déle než 3 měsíce. Možnost axiální spondylartritidy by také měla být brána v potaz v rámci diferenciální diagnostiky nejasné bolesti na hrudi u mladých pacientů. Velkým pokrokem v diagnostice časných fází onemocnění je možnost vyšetření zobrazením magnetickou rezonancí, vyžaduje však správnou volbu vyšetřovací metodiky a velkou dávku zkušenosti při hodnocení nálezů. $V$ tomto kontextu je velmi důležitá komunikace mezi revmatologem a radiologem. Významný pokrok zaznamenaly nejen diagnostické, ale i terapeutické možnosti axSpA. Nejmodernějším prvkem farmakoterapie axSpA je biologická léčba, zvláště jestliže $k$ dlouhodobě úspěšně používané anti-TNF terapii přibyla recentně nová možnost v podobě blokády IL17.

Časné rozpoznání iniciálních fází a různých fenotypů axSpA umožňuje časnější zahájení terapie s větší pravděpodobností dosažení úspěchu léčby.

\section{Literatura}

1. Baraliakos X, Braun J. Non-radiographic axial spondyloarthritis and ankylosing spondylitis: what are the similarities and differences? RMD Open 2015; 1(Suppl 1): e000053. Dostupné z DOI: <http://dx.doi. org/10.1136/rmdopen-2015-000053>.

2. de Winter JJ, van Mens LJ, van der Heijde D et al. Prevalence of peripheral and extra-articular disease in ankylosing spondylitis versus non-radiographic axial spondyloarthritis: a meta-analysis. Arthritis Res Ther 2016; 18: 196. Dostupné z DOI: <http://dx.doi.org/10.1186/s13075-016-1093-z>.

3. Tsui FW, Tsui HW, Akram A et al. The genetic basis of ankylosing spondylitis: new insights into disease pathogenesis. Appl Clin Genet 2014; 7: 105-115. Dostupné z DOI: <http://dx.doi.org/10.2147/TACG.S37325>.

4. Asquith $M$, Elewaut $D$, Lin $P$ et al. The role of the gut and microbes in the pathogenesis of spondyloarthritis. Best Pract Res Clin Rheumatol 2014; 28(5): 687-702. Dostupné z DOI: <http://dx.doi.org/10.1016/j. berh.2014.10.018>.

\section{Tab. 4. Přehled biologické terapie axSpA a efektu na jednotlivé projevy}

\begin{tabular}{|c|c|c|c|c|c|c|}
\hline \multirow[b]{2}{*}{ lék } & \multirow{2}{*}{$\begin{array}{l}\text { dávka } \\
\text { způsob aplikace } \\
\text { dávkovací interval }\end{array}$} & \multicolumn{5}{|c|}{ efekt na jednotlivé projevy axSpA } \\
\hline & & $\begin{array}{c}\text { axiální } \\
\text { projevy }\end{array}$ & $\begin{array}{l}\text { periferní } \\
\text { projevy }\end{array}$ & IBD & AAU & psoriáza \\
\hline infliximab & $\begin{array}{l}5 \mathrm{mg} / \mathrm{kg} \text { váhy } \\
\text { i.v } \\
1 \mathrm{krát} / 6 \text { týdnů + úvodně v týdnu } 0,2,6\end{array}$ & $\checkmark$ & $\checkmark$ & $\checkmark$ & $\checkmark$ & $\checkmark$ \\
\hline adalimumab & $\begin{array}{l}40 \mathrm{mg} \\
\text { s.c. } \\
1 \text { krát/2 týdny }\end{array}$ & $\checkmark$ & $\checkmark$ & $\checkmark$ & $\checkmark$ & $\checkmark$ \\
\hline etanercept & $\begin{array}{l}50 \mathrm{mg} \\
\text { s.c. } \\
1 \mathrm{krát} / 1 \text { týden }\end{array}$ & $\checkmark$ & $\checkmark$ & $x$ & $(\checkmark)$ & $\checkmark$ \\
\hline golimumab & $\begin{array}{l}50 \text { mg } \\
\text { s.c. } \\
1 \text { krát/4 týdny }\end{array}$ & $\checkmark$ & $\checkmark$ & $\checkmark$ & $\checkmark$ & $\checkmark$ \\
\hline certolizumab & $\begin{array}{l}200 \text { mg } \\
\text { s.c. } \\
1 \text { krát/2 týdny + úvodně v týdnu } 0,2,4\end{array}$ & $\checkmark$ & $\checkmark$ & $\checkmark$ & $\checkmark$ & $\checkmark$ \\
\hline sekukinumab & $\begin{array}{l}150 \text { mg } \\
\text { s.c. } \\
1 \text { krát/4 týdny + úvodně v týdnu } 0,1,2,3,4\end{array}$ & $\checkmark$ & $\checkmark$ & $x$ & 0 & $\checkmark$ \\
\hline
\end{tabular}

$\checkmark$ - účinný, x neúčinný, $(\checkmark)$ - menší efekt, o- nejsou dostačující data

indikace terapie $\mathbf{n r}$-axSpA: adalimumab, etanercept, golimumab, certolizumab 
5. Van Praet $L$, Jans $L$, Carron P et al. Degree of bone marrow oedema in sacroiliac joints of patients with axial spondyloarthritis is linked to gut infl ammation and male sex: results from the GIANT cohort. Ann Rheum Dis 2014; 73(6): 1186-1189. Dostupné z DOI: <http://dx.doi. org/10.1136/annrheumdis-2013-203854>.

6. Paine A, Ritchlin CT. Targeting the interleukin-23/17 axis in axial spondyloarthritis. Curr Opin Rheumatol 2016; 28(4): 359-367. Dostupné z DOI: <http://dx.doi.org/10.1097/BOR.0000000000000301>.

7. Jacques $P$, Lambrecht $S$, Verheugen E et al. Proof of concept: enthesitis and new bone formation in spondyloarthritis are driven by mechanical strain and stromal cells. Ann Rheum Dis 2014; 73(2): 437-445. Dostupné z DOI: <http://dx.doi.org/10.1136/annrheumdis-2013-203643>.

8. Chung HY, Machado P, van der Heijde D et al. Smokers in early axial spondyloarthritis have earlier disease onset, more disease activity, inflammation and damage, and poorer function and health-related quality of life: results from the DESIR cohort. Ann Rheum Dis 2012; 71(6): 809-816. Dostupné z DOI: <http://dx.doi.org/10.1136/ annrheumdis-2011-200180>.

9. Vander Cruyssen B, Vastesaeger N, Collantes-Estevez E. Hip disease in ankylosing spondylitis. Curr Opin Rheumatol 2013; 25(4): 448-454 Dostupné z DOI: <http://dx.doi.org/10.1097/BOR.0b013e3283620e04>.

10. Rosenbaum JT. Uveitis in spondyloarthritis including psoriatic arthritis, ankylosing spondylitis, and inflammatory bowel disease. Clin Rheumatol 2015; 34(6): 999-1002. Dostupné z DOI: <http://dx.doi. org/10.1007/s10067-015-2960-8>.

11. Van Praet $L$, Van den Bosch FE, Jacques $P$ et al. Microscopic gut inflammation in axial spondyloarthritis: a multiparametric predictive model. Ann Rheum Dis 2013; 72(3): 414-417. Dostupné z DOI: <http:// dx.doi.org/10.1136/annrheumdis-2012-202135>

12. Davey-Ranasinghe N, Deodhar A. Osteoporosis and vertebral fractures in ankylosing spondylitis. Curr Opin Rheumatol 2013 25(4): 509-516. Dostupné z DOI: <http://dx.doi.org/10.1097/ BOR.0b013e3283620777>

13. Akgol G, Kamanli A, Ozgocmen S. Evidence for inflammation-induced bone loss in non-radiographic axial spondyloarthritis. Rheumatology (Oxford) 2014; 53(3): 497-501. Dostupné z DOI: <http://dx.doi. org/10.1093/rheumatology/ket385>.

14. Gensler LS. Axial spondyloarthritis: the heart of the matter. Clin Rheumatol 2015; 34(6): 995-998. Dostupné z DOI: <http://dx.doi. org/10.1007/s10067-015-2959-1>.

15. van der Linden S, Valkenburg HA, Cats A. Evaluation of diagnostic criteria for ankylosing spondylitis: a proposal for modification of the New York criteria. Arthritis Rheum 1984; 27(4): 361-368.

16. Rudwaleit $M$, van der Heijde $D$, Landewe $R$ et al. The development of Assessment of Spondylo Arthritis international Society classification criteria for axial spondyloarthritis (part II): validation and final selection. Ann Rheum Dis 2009; 68(6): 777-783. Dostupné z DOI: <http:// dx.doi.org/10.1136/ard.2009.108233>.

17. Procházková L. Spondyloartritidy. In: Němec $P$ et al. Revmatologie pro praxi. Mladá fronta: Praha 2016: 370-389. ISBN 978-80-204-4132-4.

18. Sieper J, Poddubnyy D. Axial spondyloarthritis. Lancet 2017; 390(10089): 73-84. Dostupné z DOI: <http://dx.doi.org/10.1016/ S0140-6736(16)31591-4>.

19. Mandl $P$, Navarro-Compan $V$, Terslev $L$ et al. EULAR recommendations for the use of imaging in the diagnosis and management of spondyloarthritis in clinical practice. Ann Rheum Dis 2015;
74(7): 1327-1339. Dostupné z DOI: <http://dx.doi.org/10.1136/ annrheumdis-2014-206971>.

20. Van Heijde D, Ramiro S, Landewe R et al. 2016 update of the ASAS/ EULAR management recommendations for axial spondyloarthritis. Ann Rheum Dis 2017; 76(6): 978-991. Dostupné z DOI: <http://dx.doi. org/10.1136/annrheumdis-2016-210770>.

21. Wang R, Dasgupta A, Ward MM. Comparative efficacy of non-steroidal anti-inflammatory drugs in ankylosing spondylitis: a Bayesian network meta-analysis of clinical trials. Ann Rheum Dis 2016; 75(6): 1152-1160. Dostupné z DOI: <http://dx.doi.org/10.1136/ annrheumdis-2015-207677>.

22. Pavelka K. Doporučení České revmatologické společnosti pro léčbu ankylozující spondylitidy. Czech Rheumatology/Ces Revmatol 2012; 20(1): 4-11.

23. Baeten D, Sieper J, Braun J et al. Secukinumab, an Interleukin-17A Inhibitor, in Ankylosing spondylitis. N Engl J Med 2015; 373(26): 2534 2548. Dostupné z DOI: <http://dx.doi.org/10.1056/NEJMoa1505066>.

24. Pavelka K et al. Revmatologie. Maxdorf: Praha 2012: 294-307. ISBN 978-80-7345-295-7.

25. Haroon N, Inman RD, Learch TJ et al. The impact of tumor necrosis factor alpha inhibitors on radiographic progression in ankylosing spondylitis. Arthritis Rheum 2013; 65(10): 2645-2654. Dostupné z DOI: <http://dx.doi.org/10.1002/art.38070>.

26. Baraliakos X, Haibel $\mathrm{H}$, Listing J et al. Continuous long-term anti-TNF therapy does not lead to an increase in the rate of new bone formation over 8 years in patients with ankylosing spondylitis. Ann Rheum Dis 2014; 73(4): 710-715. Dostupné z DOI: <http://dx.doi. org/10.1136/annrheumdis-2012-202698>.

27. Poddubnyy D, Rudwaleit $M$, Haibel $\mathrm{H}$ et al. Effect of non-steroidal anti-inflammatory drugs on radiographic spinal progression in patients with axial spondyloarthritis: results from the German spondyloarthritis Inception Cohort. Ann Rheum Dis 2012; 71(10): 1616-1622. Dostupné z DOI: <http://dx.doi.org/10.1136/annrheumdis-2011-201252>.

28. Sieper J, Listing J, Poddubnyy D et al. Effect of continuous versus on-demand treatment of ankylosing spondylitis with diclofenac over 2 years on radiographic progression of the spine: results from a randomised multicentre trial (ENRADAS). Ann Rheum Dis 2016; 75(8): 1438-1443. Dostupné z DOI: <http://dx.doi.org/10.1136/ annrheumdis-2015-207897>.

29. Tubergen A. The changing clinical picture and epidemiology of spondyloarthritis. Nat Rev Rheumatol 2015; 11(2): 110-118. Dostupné z DOI: http://doi: 10.1038/nrrheum.2014>.

30. Janson RW. Ankylosing spondylitis. In: West SG. Rheumatology secrets. 3rd edition. Elsevier/Mosby 2015: 261-267. eBook ISBN: 9780323327145. eBook ISBN: 9780323172875. Paperback ISBN: 9780323037006.

31. $5 T 114$ ACR Abstract: ACR Late-Breaking Abstract. Oral presentation 2017 ACR/ARHP Annual Meeting in San Diego, California, USA.

\section{MUDr. Leona Procházková, Ph.D. \leona.prochazkova@fnusa.cz}

Revmatologická ambulance II. interní kliniky LF MU a FN u sv. Anny v Brně

www.fnusa.cz

Doručeno do redakce 30. 9. 2017

Príijato po recenzi 19. 11. 2017 